ISSN 2598-3180 (Online)

JOURNAL OF MIDWIFERY

Re se archand Practice

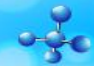

\title{
Relationship of Continuity of Midwifery Care During Antenal With Birth Preparedness in Working Area of Seberang Padang Public Health Center 2017
}

\section{Rizka Sriyouni, Lusiana El Sinta B, Aldina Ayunda Insani}

Bachelor Of Midwifery Program FK-UNAND, Jln Niaga No.56 Padang City, 25127, Indonesia

Bachelor Of Midwifery Program FK-UNAND, Jln Niaga No.56 Padang City, 25127, Indonesia

Bachelor Of Midwifery Program FK-UNAND, Jln Niaga No.56 Padang City, 25127, Indonesia

\section{SUBMISSION TRACK}

Recieved: Mei 172017

Final Revision: Agustus 18, 2017

Available Online: Nopember 24, 2017

KEYWORD

Continuity of Midwifery Care, ANC,

Birth Preparedness

KORESPONDENSI

Phone: 075120120

E-mail:

\begin{abstract}
A B S T R A C T
Continuity of midwifery care $(\mathrm{CoC})$ is one of midwifery care that's given by the same midwife during antenatal care to get birth preparedness. Birth preparedness includes recognize danger signs, identifying skilled birth attendant, identifying birth location, saving money, arranging for transportation and identifying blood donors. The objective of this study was to know the relationship of $\mathrm{CoC}$ during antenal with birth preparedness in working area of seberang padang public health center 2017.

This study is An observational analitycs with cross sectional design to 58 respondents in working area of Seberang Padang Public Health Center during December 2016 - September 2017 that are taken with consecutive sampling technique. Data collection by using a validated questionnaire and $\mathrm{MCH}$ book observation. Data were analyzed using Chi-square. From the results of the study there are $51.7 \%$ respondents who did $\mathrm{CoC}$ during ANC and 41.4\% considered being prepared in birth preparedness. The result of statistic test showed that there is relation between $\mathrm{CoC}$ during antenatal and birth preparedness ( $\mathrm{p}=0,001 ; \mathrm{OR}=8,250 ; 95 \%$ CI 2,541-26,781). So it can be concluded that There is relation between $\mathrm{CoC}$ during antenatal and birth preparedness
\end{abstract}

Keywords: Continuity of Midwifery Care, ANC, Birth Preparedness

\section{INTRODUCTION}

Antenatal Care (ANC) is the service of regular health screening of pregnant women for obstetric complications as well as diagnose to provide information about the lifestyle, pregnancy and childbirth (Backe et al, 2015). Every pregnant women is strongly recommended to get a quality comprehensive ANC at least 4 times that is at least once in first trimester (before 14 weeks gestational age), once 
in the second trimester (14-28 weeks gestation) and twice in the third trimester (28-36 week and after 36 weeks gestational age) include at least once visit with husbands or family members. The first visit of the ANC is highly recommended on 8-12 weeks gestational age (Backe et al, 2015; Kemenkes RI, 2015; Permenkes 97, 2014). In the year 2015 , nearly all pregnant women $(95.75 \%)$ in Indonesia has already done the first visit ANC (K1) and $87.48 \%$ of pregnant women have already done complete visit with a frequency of at least 4 times (K4) (Kemenkes RI, 2016).

The one of purpose the ANC is preparing for a woman in labor and birth (NICE, 2012). The birth preparedness is the initial planning and preparation for childbirth that aims to help women, husband and family in order to be ready to give birth by making plans face complications and unexpected things (FCI, 2016; WHO, 2006). The birth preparedness can be used to measure at six different level such as the individual women, her family (husband/ partner), the community, the healthcare provider, the health facility and the policy environment. At the individual level, pregnant women and their partners can prepare by learning to recognize danger signs that may indicate life-threatening complications for the mother and baby, identifying a skilled provider and a birth location, saving money, and arranging for transportation, identify blood donors (JHPIEGO, 2004; WHO, 2006). A woman who has been preparing the sixth element of the birth preparedness that has been described WHO categorized "prepare" and when has been preparing less than sixth element ofbirth preparedness categorized "unprepared" (Gitonga, 2014).

Some research suggests that still lack women who categorized prepared preparedness in thebirth Kumar, 2015; Bintabara et al, 2015). According to Gebre et al (2015) one of the factors that encourage the birth preparedness was the ANC. There is a higher proportion of prepare in women who do visit ANC 4 times or more than the visit to the ANC less than 4 times (Bintabara et al, 2015; Gitonga, 2014).

In addition to aiming to prepare for childbirth, according to Adriaansz in Saif (2013), one of the important reasons pregnant women should get the service of the ANC is to build mutual trust between the client and the health workers. Backe et al (2015) recommended to try the continuity of care $(\mathrm{CoC})$ in order for the client to know the caregivers. Continuity of care is one model of midwifery care that provides service in helping women build a relationship with the same care givers (can be either group) while pregnant, maternity and childbirth (Henderson et al., 2007). Continuity of care is one way to improve the overall service quality to decrease maternal and infant mortality. Continuity of care is sorely needed at each cycle of the life of one of them during pregnancy (Renfrew et al, 2014; Kerber et al, 2007).

ANC can be granted by the competent health worker such as doctor, midwives and nurses trained, in accordance with the applicable provision (Permenkes, 97, 2014). In general 80$90 \%$ pregnancy take place physiologically, and only $10-20 \%$ of pregnancy will be accompanied with complication. Midwives in the materal health care have the authority to provide antenatal service in normal pregnancies (Permenkes, 28/2017). The results of the Basic Health Research (Riskesdas) in the year 2013 shows that $88 \%$ of antenatal services provided by midwives, and $52.5 \%$ were implemented in the practice of midwifery (Kemenkes RI, 2013).

This research aims to know the relationship of continuity of midwifery care in antenatal with birth preparedness in working area of Seberang Padang Public Health Center 2017.

\section{METHODS}

This research is observational analytic with cross sectional design performed in working area of Seberang Padang Public Health Center during December 2016-September 2017 with samples is the women in a period of 6 weeks postpartum who meets the criteria of inclusion that is willing to be the respondents, did the ANC with midwives, according to the standard, has a $\mathrm{MCH}$ book and no complication in pregnancy that add up to 58 people were taken with the consecutive sampling technique. The independent variable in this study is continuity of midwifery care in antenatal wherea the dependend variable is birth preparedness obtained through interviews using questionnaires that Safe Motherhood Prototype modified from a Questionnaire from The Monitoring of Birth Preparedness and Complication Readiness (BP/CR): Tools and Indicators forMaternal and Newborn Health JHPIEGO which has been validated and the observation $\mathrm{MCH}$ book. Respondents 
categorized $\mathrm{CoC}$ in the $\mathrm{ANC}$ when pregnant women checks $\geq 4$ times according to the standard, with one of the same midwife and had been getting advice in pregnancy and childbirth, categorized prepared in birth preparedness when knowing $\geq 6$ items the birth preparedness described WHO. All data is processed using SPS with Chi Square test $\mathrm{p}$ value $<0.05$. This study was approved by The Committee of the Research Ethics of the Faculty of Medicine, Andalas University.

\section{RESULT}

Sosiodemografi characteristics of respondents frequency distribution can be seen in table 1 below:

Table 1 Characteristics of Sosiodemografi Respondents

\begin{tabular}{lcc}
\hline Characteristic & n & \% \\
\hline Maternal age (year) & 2 & 3,5 \\
<20 & 54 & 93,1 \\
$20-35$ & 2 & 3,5 \\
$>35$ & & \\
Parity & 22 & 37,9 \\
$\quad$ Primipara & 36 & 62,1 \\
Multipara & & \\
Maternal education & 1 & 1,7 \\
Illiterate & 3 & 5,2 \\
Elementary & 13 & 22,4 \\
Junior high school & 30 & 51,7 \\
Senior high scholl & 11 & 19,0 \\
University & & \\
Maternal employment & 0 & 0,0 \\
Traders & 45 & 77,6 \\
$\quad$ House wife & 0 & 0,0 \\
Labour/ farmer & 7 & 12,1 \\
Civil servant & 6 & 10,3 \\
$\quad$ Self employed & & \\
Paternal education & 0 & 0,0 \\
Illiterate & 3 & 5,2 \\
Elementary & 6 & 10,3 \\
Junior high school & 36 & 62,1 \\
Senior high scholl & 13 & 22,4 \\
University & & \\
Paternal employment & 58 & 100,0 \\
Work & 0 & 0,0 \\
\hline not work & $\mathbf{5 8}$ & $\mathbf{1 0 0 , 0}$ \\
\hline$\quad$ All & &
\end{tabular}

Based on table 1, it can be noted that for the majority of maternal age category at the age of 20 to 35 years is $93.1 \%$. Based on parity that the majority of the respondents i.e. multipara category is $62.1 \%$. Based on the educational level of the mother it is known that the majority of high school graduates is $51.7 \%$. Based on the work, it is known that the majority of the respondents is a housewives as $77.6 \%$. Based on the level of education is well known that the majority of the respondents husband is graduating high school is $62.1 \%$. Based on the work of the husband of the respondents note that entirely had the job.

Table 2. Frequency Distribution of $\mathrm{CoC}$ in antenatal

\begin{tabular}{|c|c|c|}
\hline $\mathrm{CoC}$ in antenatal & $\mathbf{n}$ & $\%$ \\
\hline Yes & 30 & 51,7 \\
\hline No & 28 & 48,3 \\
\hline All & 58 & 100 \\
\hline
\end{tabular}

Based on table 2 noted that the majority of respondents classified as $\mathrm{CoC}$ in antenatal is $51.7 \%$.

Table 3. Frequency distribution element of birth preparedness

\begin{tabular}{lcc}
\hline \multicolumn{1}{c}{ Element of birth preparedness } & n & \% \\
\hline learning to recognize danger signs & 36 & 62,1 \\
identifying a skilled provider & 49 & 84,5 \\
identifying a birth location & 41 & 70,7 \\
saving money & 46 & 79,3 \\
arranging for transportation & 47 & 81,0 \\
identifying blood donors & 35 & 60,3 \\
\hline
\end{tabular}

Based on table 3 it can be noted that the majority of respondents to better prepare each elements in the birth preparedness of which namely $62.1 \%$ of respondents had learning to recognize danger signs in pregnancy, childbirth, postpartum and newborn, $84.5 \%$ of respondents identifying a skilled provider, $70.7 \%$ of respondent identifying healthcare facilities, $79.3 \%$ of respondents saving money, $81.0 \%$ of the respondents arranging for transportation and $60.3 \%$ of respondents identifying blood donors.

Table 4. Frequency Distribution of Birth preparedness

\begin{tabular}{|c|c|c|}
\hline Birth preparedness & $\mathbf{n}$ & $\%$ \\
\hline Prepared & 24 & 41,4 \\
\hline Unprepared & 34 & 58,6 \\
\hline All & 58 & 100 \\
\hline
\end{tabular}

Based on table 4 note that the respondents are categorized prepared in birth preparedness just $41.4 \%$. According to the WHO (2006) the birth preparedness are not easy to achieve especially in developing countries.

Table 5. Relationship of $\mathrm{CoC}$ in ANC with birth preparedness

\begin{tabular}{llll}
\hline CoC in & Birth preparedness & OR & p \\
\hline
\end{tabular}




\begin{tabular}{lcccccc}
\hline \multirow{2}{*}{ ANC } & \multicolumn{2}{c}{ unprepared } & \multicolumn{2}{c}{ prepared } & \multicolumn{1}{c}{$\mathbf{( 9 5 \%}$} & \\
\cline { 2 - 5 } & $\mathbf{n}$ & $\mathbf{\%}$ & $\mathbf{N}$ & $\mathbf{\%}$ & $\mathbf{C I})$ & \\
\hline No & 26 & 92,9 & 2 & 7,1 & 8,250 & \\
Yes & 8 & 26,7 & 2 & 73,3 & $(2,541-$ & 0,001 \\
& & & 2 & & $26,781)$ & \\
\hline
\end{tabular}

Based on table 5 note that the respondents who do not $\mathrm{CoC}$ in antenatal only 7.1\% categorized prepare, while respondents who do the $\mathrm{CoC}$ in the antenatal, note that the majority belongs to prepare is $73.3 \%$. The results of statistical tests obtained $p$ value $=0.001$ then can be concluded there is a significant relationship between the $\mathrm{CoC}$ in antenatal with birth preparedness. From the results of the analysis of the obtained values OR also $=8,250$, meaning when the women do $\mathrm{CoC}$ in antenatal 8.25 times have the opportunity to be prepared in the birth preparedness than women don't $\mathrm{CoC}$ in antenatal

\section{DISCUSSION}

In antenatal visits, pregnant women will get service with a 10T standard one is the appointment speech (counseling) provided since the first contact. Material presented includes: a). Preparation and delivery readiness face complications, b). Initiation of early and exclusive breast milk, c). Postpartum family planning, d). The problem of nutrition, e). TT Immunization in pregnant women, f). Problems of chronic illness and disease contagious, $g$ ). The class mother, h). Brain booster, i). Information on HIV/AIDS (PMTCT/PPIA) and IMS, j). Information of violence against women. As for the content of messages conveyed health workers at the time of counseling about birth preparation and readiness of facing complications i.e. danger signs in pregnancy, labor and childbirth, motherhood maternity, where savings in labor, transportation reference, helper in childbirth, the prospective blood donors, labor companion and husband standby (Permenkes, 97, 2014; Kemenkes RI, 2010b).

The birth preparedness is an important component in the antenatal service (ANC)and is one of preventive health efforts mainly to reduce maternal and neonatal mortality and morbidity and because "Three Delays Model" (PMNCH, 2006; Saultz and Lochner, 2005; JHPIEGO, 2004). Research of Bintabara et al (2015), Gebre et al (2015) and Gitonga (2014), one of the predictors of factors related to the birth preparedess was the visit of ANC. Women who did ANC visit 4 times or more have a proportion of birth preparedness is higher than in women who did visit the ANC less than 4 times. It is due to a good opportunity or entry point for health workers to inform and assist pregnant women in planning components important the birth preparedness at the time of the visit of ANC (Gebre et al, 2015).

In this study researchers focused not only on the quantity of visits the ANC alone, but also on kontinuitasnya. According to Gitonga (2014), with ANC visits 4 times or more will make pregnant women more cared for by midwives, especially when done at the same midwife or called $\mathrm{CoC}$ in ANC. A review showed that $\mathrm{CoC}$ relates significantly to health outcomes, and there is a positive relationship between the $\mathrm{CoC}$ with preventive health efforts including one is the birth preparedness (Saultz and Lochner, 2005).

The CoC's model will increase the sense of satisfaction in women as well as make more women know and trust such as the giver's midwife during her pregnancy (Macdonald and Magill-Cuerden, 2013; NSW Health, 2012; DOH, 2007; Henderson et al, 2007). With the model's $\mathrm{CoC}$, midwives have time

for discussions with expectant mothers so that a midwife will understand the wants and needs of women-centered. Therefore, the continuity of care of that is continuity of management, continuity of of relationships al, 2003). Thus, information and continuity to pregnant women at the time of appointment will be continuous speech between visits is mainly about the birth preparedness. Beliefs of pregnant women to midwives would be beneficial on compliance with the information given.In addition, the midwife can also help expectant mothers in childbirth preparation and conduct follow-up to information that has been provided earlier so that expectant mothers who do the CoC in the ANC can be better prepared in birth

preparedness. Therefore the expected deploymen $\mathrm{t}$ model orphanage $\mathrm{CoC}$ can be maintained.

Respondents are classified as ready in the birth preparedness only a small part of it, although it is known that each of 
the elements in the birth preparedness has been prepared by a majority of the respondents. The birth preparedness is indeed not easy to achieve especially in developing countries. However, low delivery readiness can also be attributed to the quality of ANC given by health workers. It is mainly on the quality of information at the time of appointment a speech given to the mother and the husband in this case about the birth preparedness (Gebre et al, 2015; Kabakyenga et al, 2011).

In this research, the quality of appointment speech at a time when the ANC was given by a midwife to mother and the husband is not made observation directly. To ensure that the respondents have been getting advice during pregnancy is done using questionnaire interviews with researchers and see documentation on MCH'S book. It certainly raises a lot of weakness so that direct observation needs to be done to assess the quality of the information obtained by the respondents when the speech appointment.

The readiness of the delivery is not only affected by antenatal visits, but can also be influenced by a number of other things. According to the WHO (2006), the birth preparedness in developing countries are difficult to achieve because of the populationon average live with income less than US \$1 per day. This is certainly hardly enough for them to meet the needs of food and clothing much less to set aside money as a preparation in case of obstetric kegawatdaruratan.

A Research by A Nurdiyan, YY Yulizawati, LE Bustami, D Iryani in 2014 conclude that Antenatal class is a way for pregnant women to study together to obtain proper knowledge, for preventing from complication, increasing coverage of antenatal visits, and having child delivery at the health care practitioner and also prepare women for delivery. In every visit of antenatal class Women and father fasilitate to increase their understanding about what happen during labor and delivery, so that by followong antenatal class regularly Women and family will be more prepare to do normal delivery (Nurdiyan, A et al 2014)

Associated with the income, according to the NCO et al (2015) husband who works is known to also have an effect on the readiness of the birthing woman. Women with low incomes husbands would feel less need to birth preparedness plans carried out and could not be implemented due to financial constraints. In contrast, women with husbands whose incomes are enough then there will be the money that can be saved and used when in a State of emergency which is one element of birth preparedness (Gitonga, 2014).

From this research it is known that the whole of the respondent's husband has a job. The results of this study are in line with studies Bintabara et al (2015) and Gitonga(2014) above that respondents with husbands who work tend to be better in the birth preparedness. It can be seen that the majority of respondents to better prepare each elements in the readiness of the delivery one is regulating finance. As for the small percentage that does not prepare the Treasury due to already have health insurance. However, this study did not examine family income as in the research of Bintabara et al (2015) and Gitonga (2014). Therefore, the need to further research with studies on family income. In addition, a the birth preparedness provide information mainly on financial elements in order to be better able to encourage mother and husband to save money or have health insurance.

In addition to related to the family income, in the research of Affipunguh and Laar(2016), low level of birth preparedness in developing countries is also related to the area of residence and level of education of the mother. The situation in rural areaswill be more complex both in terms of income as well as the availability of transport.Even if the transportation is available and the money to pay for it is precisely the distance and roads less worthy causes can

be a factor late in the life of a woman in the obstetrical kegawatdaruratan (WHO, 2006).

The level of secondary education and above are known to have synergistic effects against the birthpreparedness

(Affipunguh and Laar, 2016). This is because the mother has reached the level of secondary education and above will better understand the importance of birth preparedness so that it will adhere to the counselling provided. In addition, an educated mother will also have a level of awareness about better health and have the ability and quality for the 
health-

related decisions (Bintabara etal, 2015; Tilahun a nd Sinaga, 2015; Emma-

Ukaegbu etal, 2014; Gitonga et

al, 2014;Kabakyenga et al, 2011).

Mother's education, not only in research and Kumar Mutreja (2015) found a connection between education husband with the readiness of childbirth. Mother with a husband that cultured over base would be better in the birth preparedness. This is because an educated husband will be better able to understand information gained fromgood health health workers as well as from various other sources as well as an indication that the husband is the decision maker in the family effect on his wife to use maternal health services (Tilahun and Sinaga, 2015).

In this study the majority of education respondents as well as respondent's husbandis graduating high

school. This is certainly will increasingly support the birth preparedness especially when done with the model of CoC in the ANC. However, it should be noted again the quality of granting of information readiness appropriate levels of education so that labor can be understood by women and her husband from the various levels of education so that it is able to improve the birth preparedness.

According to Kabakyenga et al (2011), age of mother under 25 years of age are known to have a synergistic effect in conjunction with the birth preparedness. This is indicated from the survey reports health in Uganda that young women aged less than 25 years of age have a higher ratio in the ANC visits compared to women aged $\geq 25$ years. Different case with according to Gitonga (2014) that the age is not significant effect against the birth preparedness. Thi is because most respondents indicated high readiness are on age range 40-44 years and conversely the lowest readiness is the age of 30-34 years.

In this study, the majority of respondents are at 20-35 years of age. According to Affipunguh and Laar (2016) the existence of variations in the birth preparedness and environmental differences make it difficult to compare findings with other studies from many countries. As well as the need to maintain and enhance the birth preparedness for all age groups prior to the age groups at risk.
According to Gebre et al (2015), parity is one of the other predictors of factors related to the birth preparedness. Mother in primipara better birth preparedness due tothe perception that they are at high risk and do not have the experience like a multipara. According to Gitonga (2014) women who have given birth to many times not to feel the need to plan the birth preparedness because of the mindset to follow the trend in the previous pregnancy.

In this study, the majority of respondents are a multipara. The results of the birth preparedness which is still low in this research line with research Gebre et al (2015) and Gitonga (2014) that tends to be better in the primipara readiness childbirth compared multipara. However, the respondents in the study used more and selected bymultistage random sampling that is certainly more research results can be generalized to the population in this study compared with a sample minimal and selected by nonprobability sampling. Therefore, the need to further research by the method of sample selection. In addition, at a time when the ANC health workers also need to emphasize again about the birth preparedness in multipara.

\section{The Limitations Of The Research}

This study has been organised and carried out in accordance with the scientific procedure, however still has limitations:

1. data collection research carried out using a questionnaire that was interviewed by researcher so that they can give rise to subjectivity and sometimes the answers given by respondents do not show the real state

ofaffairs. Respondents tend to answer the id eal may not correspond to the actual conditions. The truth of the collected data depends on the honesty and seriousness of respondents in answering the questionnaire. In addition, the weakness of the instruments using a questionnaire that the questions in the questionnaire a closed shape, structured so as not to open up opportunities for other answers he made by the respondent.

2. In addition to using the primary data with questionnaires, secondary data collection is also done by looking at the antenatal service documentation. Antenatal s 
ervice quality is not observed directly due to the limitations of the research design used.The weakness of the instrument using the documentation that health workers likelywill make the ideal service and documentation appropriate standards that may not be in accordance with the conditions of the service provided.

3. The respondents in this study is in period 6 weeks postpartum is so in conducting interviews occasionally interview process plagued with the condition around like babies fuss and should be breast fed or the presence of guests who visit to see a newborn.
4. Research involving a limited number of research subjects, i.e. as many as 58 people, so that the results could not be generalized to a group of subjects with large numbers. The sample used is necessary plus the amount so that the result is more accurate.

\section{CONCLUSSION}

There is a meaningful relationship between the

continuity of midwifery care in antenatal with bir th preparedness in the region of clinics across the Pasture year 2017 


\section{REFERENCES}

Affipunguh, P.K dan A.S, Laar. 2016. Assesment of Knowledge and Practice towards Birth Preparedness and Complication Readiness among Women in Northern Ghana : a Cross-sectional Study. International Journal of Science Reports 2 (6) : 121 - 129

A Nurdiyan, YY Yulizawati, LE Bustami, D Iryani. 2014. Analisis pelaksanaan kelas ibu hamil di Kabupaten Agam.. Journal of Midwifery 1 (1), 45-54.

Backe, B., A.S. Pay., A. Klovning., dan S. Sand. 2015. Antenatal Care. Diakses pada 3 Desember 2016. Tersedia di http://www.nfog.org/files/guidelines/1\%20NGF\%20Obst\%20Antenatal\%20care\%20Backe.pdf

Bintabara, D., M.A, Mohamed., J, Mghamba., P, Wasswa dan R.N.M, Mpembeni. 2015. Birth Preparedness and Complication Readiness among Recently Delivered Women in Chamwino District, Central Tanzania : a Cross Sectional Study. Reproductive Health $12: 44$

Departement of Health. 2007. Maternity Matters : Choice, Access and Continuity of Care in Safe Service. NHS. London

Emma-Ukaegbu, U.C., H.I, Nwokeukwu dan B.S.C, Uzochukwu. 2014. An Assesment of Birth Preparedness and Complication Readiness in Antenatal Women in Umuahia North Local Government Area, Abia State, Nigeria. IOSR Journal of Dental and Medical Sciences 13 (1) : 90-94

Family Care International. 2016. Birth Preparedness : an Essential Part of ANC Counselling. The Skilled Care Initiative. New York

Gebre, M., A, Gebremariam dan T.A, Abebe. 2015. Birth Preparedness and Complication Readiness among Pregnant Women in Duguna Fango District, Wolayta Zone, Ethiopia. PlosOne 10 (9)

Gitonga, M.E. 2014. Birth Preparedness among Women in Tharaka, Nithi County, Kenya. Kenyatta University. Kenya

Haggerty, J.L., R.J, Reid., G.K, Freeman., B.H, Starfield., C.E, Adair dan R, McKendry. 2003. Continuty of Care : a Multidisciplinary Review. BMJ 327 : 1219-21

Henderson, J., J, Hornbuckle dan D, Doherty. 2007. Models of Maternity Care: a Review of the Evidence. DOH. Subiaco

JHPIEGO, MNH dan Family Care International. 2004. Monitoring Birth Preparedness and Complication Readiness Tools and Indicators for Maternal and Newborn Health. JHPIEGO. USA

Kabakyenga, J., O, Per-Olof., T, Eleanor dan O.P, Karen. 2011. Knowledge of Obstetric Danger Sign and Birth Preparedness Practice among Women in Rural Uganda. Reproductive Health 8(33)

Kementerian Kesehatan Republik Indonesia. 2010b. Pedoman Pelayanan Antenatal Terpadu. Kemenkes RI. Jakarta 2013. Riset Kesehatan Dasar 2013. Kemenkes RI. Jakarta 2015. Buku Ajar Kesehatan Ibu dan Anak. Kemenkes RI. Jakarta 2016. Profil Kesehatan Indonesia Tahun 2015. Kemenkes RI. Jakarta 
Kerber, K.J., J.E, de Graft-Johnson., Z.A, Bhutta., P, Okong., A, Starrs dan J.E Lawn. 2007. Continuum of Care for Maternal, Newborn and Childhealth : from Slogan to Service Delivery. Lancet 370 : 135869

Macdonald, S dan J, Magill-Cuerden. 2013. Mayes'Midwifery Fourteenth Edition. Elsevier. Edinburgh

Mutreja, S dan A, Kumar. 2015. Knoowledge and Practice of Birth Preparedness among Tribal Women in Sukma District of Chhattisgarh, India. IOSR Journal of Humanities and Social Science 20 (3) : 66-71

National Institute for Health and Care Excellence. 2012. Antenatal Care. Diakses pada 3 Desember 2016. Tersedia di : https://www.nice.org.uk/guidance/qs22/resources/antenatal-care-2098542418117

NSW Ministry of Health. 2012. Midwifery Continuity of Carer Model Tool-kit. NSW. North Sydney

Peraturan Menteri Kesehatan Republik Indonesia Nomor 28 Tahun 2017 Izin dan Penyelenggaraan Praktik Bidan. 13 Juli 2017. Berita Negara Republik Indonesia Tahun 2017 Nomor 954. Jakarta

Peraturan Menteri Kesehatan Republik Indonesia Nomor 97 Tahun 2014 Pelayanan Kesehatan Masa Sebelum Hamil, Masa Hamil, Persalinan, dan Masa Sesudah Melahirkan, Penyelenggaraan Pelayanan Kontrasepsi, serta Pelayanan Kesehatan Seksual. 30 Desember 2014. Berita Negara Republik Indonesia Tahun 2014 Nomor 135. Jakarta

Renfrew, M.J., C.S.E, Homer., S, Downe., A, McFadden., N, Muir., T, Prentice dan P.T, Hoope-Bender. 2014. Midwifery is a Vital Solution to the Challenges of Providing High-quality Maternal and Newborn Care for All Women and Newborn Infants, in All Countries. The Lancet Juni 2014

Saifuddin, A.B. 2013. Ilmu Kebidanan. PT Bina Pustaka Sarwono Prawirohardjo. Jakarta.

Saultz, J.W dan J, Lochner. 2005. Interpersonal Continuity of Care and Care Outcomes : a Critical Review. Annals of Family Medicine 3 (2) : 159-166

The Partnership for Maternal, Newborn and Child Health. 2006. Opportunities for Africa's Newborns: Practical Data, Policy and Programmatic Support for Newborn Care in Africa. WHO. Geneva

Tilahun, T dan M, Sinaga. 2016. Knowledge of Obstetric Danger Signs and Birth Preparedness Practices among Pregnant Women in Rural Communities of Eastern Ethiopia. International Journal of Nursing and Midwifery 8 (1) : 1-11

WHO. 2006. Birth and Emergency Preparedness in Antenatal Care. WHO. Geneva 